\title{
Kajian Tipologi Sufiks -an dalam Bahasa Indonesia
}

\author{
M. Suryadi \\ Fakultas Ilmu Budaya, Universitas Diponegoro \\ Email: mssuryadi07@gmail.com
}

\begin{abstract}
In Indonesian language, the study of suffix " $-a n$ " has been widely practiced by linguists, as if the study of suffix "-an" has been completed and there was no problem. Behind that, the rule of certainty about the suffix "-an" has not been convincingly revealed, wheater it is related to necessity, probability, and certainty.Through typology studies can be found the rules of certainity suffix "-an". Surely, there will be found three rues: first the rule of suffix "-an", second the rule of stability of the suffix "-an", and third the rule of the suffix "-an" position on the sentence relation. Further findings on setencial relations: the presence of the suffix -an determined by verbal form. In relation S-V-O suffix -an always occupy the argument. Suffix -an have the ability to change all categorical word into a noun category except the category of adverbs.
\end{abstract}

Keywords: rules, certainly, relation, suffix, typology

\section{Intisari}

Penelitian sufiks -an dalam bahasa Indonesia telah banyak dilakukan oleh para linguis, seolah-olah penelitian terhadap sufiks -an telah tuntas dan tidak ada persoalan lagi. Di balik itu, ternyata kaidah kepastian perihal sufiks -an belum diungkap secara meyakinkan, baik yang terkait dengan keniscayaan, kemungkinan, dan kepastian. Melalui kajian tipologi dapat ditemukan kaidah kepastian sufiks -an. Hal yang pasti, yakni ditemukan tiga kaidah: pertama kaidah kedudukan sufiks -an, kedua kaidah kemantapan ujud sufiks -an, dan ketiga kaidah kedudukan sufiks - an pada relasi sentencial. Temuan lebih lanjut pada relasi setencial: kehadiran sufiks -an ditentukan oleh bentuk verbal. Pada relasi S-V-O sufiks - an selalu menempati fungsi argument. Sufiks - an mempunyai kemampuan mengubah semua kategorial kata ke dalam kategori nomina kecuali pada kategori adverbia.

Kata kunci: kaidah, niscaya, relasi, sufiks, tipologi.

\section{Pendahuluan}

Kajian tipologi terhadap sufiks - an dalam bahasa Indonesia tidak dapat dilepaskan dengan persoalan (1)hal yang niscaya, (2) hal yang mungkin, dan (3) hal yang pasti. Ketiga faktor tersebut dikaitkan pula dengan hasil-hasil penelitian yang dilakukan oleh linguist pendahulu, sebagai salah satu strategi untuk memperoleh kajian akhir yang komprehensif.

Temuan yang dilakukan oleh linguist pendahulu dimanfaatkan sebagai kajian awal untuk menelusuri temuan yang pernah dicapai. Diharapkan temuan tersebut dapat 
dipetakan untuk mengetahui kesinambungan temuan baik berdasarkan kurun waktu maupun kualitas subtansi.

Pemetaan kurun waktu diharapkan dapat diketahui alur keterkaitan dan saling keberpengaruhan antar linguist dalam memandang sufiks - an. Sedang substansi lingual dimanfaatkan untuk mengetahui kecermatan dan kedetailan dalam mengupas sufiks $-a n$, yang seolah-olah telah tuntas.

Penelitian sufiks -an telah banyak dilakukan oleh para linguis dan seolah-olah penelitian terhadap sufiks - an tersebut sudah tuntas dan tidak ada persoalan. Namun, timbul pertanyaan apakah sejauh ini telah ditemukan kaidah yang pasti tentang sufiks an? Untuk menyakinkan hipotesis tersebut akan ditelusuri beberapa linguis dengan hasil temuannya.

Soetarno (1965:47-53), fungsi akhiran - an ialah sebagai pembentuk kata benda dari jenis kata yang lain, yakni kata kerja, kata benda, kata keadaan, dan kata bilangan. Namun, pada saat tertentu dapat juga berfungsi sebagai kata keadaan meskipun tidak terlalu banyak.Makna yang ditimbulkan akhiran -an adalah menyatakan tempat. Tetapi arti pokok tempat semakin lama semakin meluas dan menjadi bermacam-macam pengertian bergantung kepada jenis kata dasarnya dan hubungan dalam kalimat. Adapun maknanya adalah Bila kata dasarnya kata kerja maka makna yang ditimbulkan menyatakan: tempat melakukan perbuatan, alat melakukan perbuatan, cara melakukan perbuatan, hasil perbuatan, dan yang (biasa, telah atau dapat) dikenai perbuatan.Bila kata dasarnya kata benda maka makna yang ditimbulkan menyatakan: himpunan benda sejenis, mempunyai/banyak tentang benda yang tersebut pada kata dasarnya, tiap-tiap, bila kata dasarnya kata yang menunjuk ukuran atau waktu, serupa (tiruan) atau bermacam-macam, bila kata dasarnya berbentuk kata ulang.Bila kata dasarnya kata keadaan maka makna yang ditimbulkan adalah menyatakan nama benda yang mempunyai sifat yang disebut pada kata dasarnya, dan menyatakan lebih.

Keraf (1982:109-110), sufiks - an sangat produktif dalam bahasa Indonesia. Morfem terikat ini tidak mengalami perubahan bentuk dalam penggabungannya dengan unsur-unsur lain.Sufiks - an berfungsi membentuk kata benda. Akibat pengaruh dari beberapa bahasa daerah atau pengaruh dari beberapa dialek, sufiks - an dapat berfungsi membentuk kata sifat. Namun fungsi sebagai pembentuk kata sifat diakui oleh Keraf (1982:109) belum produktif. Sufiks - an mengandung arti sebagai berikut, (1) tempat, (2) perkakas atau alat, (3) hal atau cara, (4) akibat atau hasil perbuatan, (5) sesuatu 
yang di.... (6) sesuatu yang telah....(7) seluruh atau himpunan, (8) menyerupai atau tiruan dari (9) tiap-tiap, (10) sesuatu yang mempunyai sifat seperti yang disebut pada kata dasarnya, (11) intensitas baik mengenai kuantitas maupun kualitas.

Ramlan (1983: 139-143), sufiks - an dapat dilihat dari dua sisi, yakni sisi bentuk dan makna. Sisi bentuk mencakup (1) sufiks - an melekat pada bentuk dasar yang termasuk golongan kata kerja, (2) sufiks - an melekat pada bentuk dasar yang berupa pokok kata, (3) sufiks - an melekat pada bentuk dasar yang berupa kata nominal, (4) sufiks - an melekat pada bentuk dasar yang berupa kata bilangan.Sufiks -an hanya mempunyai satu fungsi sebagai pembentuk kata nominal.

Sisi makna sufiks -an menyatakan (1) sesuatu yang berhubungan dengan perbuatan yang tersebut pada bentuk dasarnya. Sesuatu ini menyatakan hasil perbuatan, alat, atau yang dikenai perbuatan; (2) menyatakan tiap-tiap; (3) menyatakan sesuatu yang terdiri dari apa yang tersebut pada bentuk dasarnya, (4) sufiks - an menyatakan beberapa; (5) menyatakan sekitar.

Moeliono (1988: 93, 159, 227), memberikan ulasan perihal sufiks -an, sebagai berikut. Sufiks -an tidak mengalami perubahan bentuk jika digabungkan dengan kata manapun juga. Jika fonem terakhir suatu dasar adalah /a/ maka dalam tulisan fonem itu dijejerkan saja dengan sufiks -an. Contoh: berduaan, bersamaan.Sufiks -an pada pembentukan nomina memiliki arti umum, yakni hasil tindakan yang dinyatakan oleh verba dengan meng- atau apa yang di....Subkelompok nomina dengan sufiks -anlebih banyak mengacu ke tempat dan waktu yang berkala. Adverbial cara yang memakai reduplikasi dengan sufiks - an mempunyai arti menyatakan cara yang dilakukan sampai ke titik yang paling tuntas.

\section{Metode Penelitian}

Metode penelitian yang digunakan dalam kajian ini mengikuti pola kerja yang dilakukan oleh Joseph H. Greenberg (1978) dan Sudaryanto (1993). Pola kerja Greenberg (1978) dimanfaatkan untuk menelusuri hal yang niscaya, hal yang mungkin, dan hal yang pasti yang terkait dengan komponen bahasa: sufiks -an.

Pola kerja Sudaryanto (1993) diikuti dengan berpedoman bahwa sebuah analisis dapat dipandang selesai manakala telah ditemukan kaidah yang mengatur objek yang sedang menjadi sasaran penelitian. Penentuan sebuah kaidah mencakup empat aspek yang dipastikan harus ada, yakni: domain atau lingkup berlakunya kaidah, constraint 
atau batas jangkau kaidah, jenis-jenis atau aneka macam tipe kaidah, relasi antarkaidah, dan kaidah yang ditemukan mendasari adanya kaidah yang lain.

\section{Pembahasan Tipologi Sufiks -an}

\section{Hal yang Niscaya}

Hal yang niscaya bertautan dengan sesuatu yang tidak bisa dipungkiri atau sesuatu yang tidak dibantahkan walau oleh linguist siapa pun. Hal yang niscaya terjadi karena berkaitan dengan hal yang pasti.Keniscayaan atau sesuatu yang tidak terbantahkan pada sufiks - an adalah - an sebagai sufiks selalu melekat di belakang satuan dasar lain dan an baru dikatakan sufiks bila telah melekat pada satuan dasar lain dan berpadu menjadi satuan dasar yang polimorfemis.

Penentuan kaidahnya dapat diformulasikan sebagai berikut.

$$
\text { Kaidah 1: Kedudukan Sufiks -an }
$$

$$
\{\text { Satuan Dasar }+ \text {-an }\}
$$

Polimorfemis

\section{Hal yang Mungkin}

Hal yang mungkin ini selalu berkaitan dengan kemungkinan-kemungkinan yang dapat terjadi. Pada kajian ini memanfaatkan kemungkinan-kemungkinan tersebut dan tidak dapat lepas dari polah intuisi penulis untuk terus mencoba dengan segala daya upaya dan kemampuannya. Untuk tercapainya hal ini, harus benar-benar dapat memahami identitas kelingualan fenomena sentencial yang terjadi pada sufiks -an. Dengan demikian, dalam pemahaman tersebut tidak dapat terlepas dari aspek formal dan semantiknya.

Aspek formal terkait dengan bentuk sufiks - an dengan daya lekat pada satuan dasar. Satuan dasar apa saja yang dapat dilekati oleh sufiks -an. Aspek semantik bertautan dengan makna yang ditimbulkan akibat dari pelekatan sufiks - an pada satuan dasarnya.

\section{Aspek Formal}

Aspek formal terkait dengan bentuk sufiks - an dengan daya lekat pada satuan dasar. Satuan dasar apa saja yang dapat dilekati dengan sufiks -an. 
(1) tidur +- an $\rightarrow$ tiduran

(2) makan +-an $\rightarrow$ makanan

(3) tambah +- an $\rightarrow$ tambahan

(4) jadi +- an $\rightarrow$ jadian

(5) dua $+-a n \rightarrow d u a a n$

(6) jago +- an $\rightarrow$ jagoaan

Tampaknya sufiks -antidak mengalami perubahan bentuk jika digabungkan dengan satuan dasar manapun juga, baik satuan dasar yang berakhir dengan fonem konsonan atau fonem vocal. Dengan demikian dapat dibentuk kaidah dengan formula sebagai berikut.

Kaidah 2: Kemantapan Ujud Sufiks - an

$\{$ satuan dasar/-k/v\# + -an $\rightarrow$ satuan dasar +- an $\}$

Berdasarkan kaidah 2 di atas sufiks -anmemiliki daya gabung dengan satuan dasar. Hanya yang menjadi persoalan, satuan dasar yang mana dan berkategori apa? Apakah semua kategori dapat dilekati sufiks - an? Untuk itu, daya lekat sufiks -an akan diuji coba melalui analisis di bawah ini.

\section{Kategori Verba}

(1) makan

(1a) Ia makan roti (verba)

(1b) Di meja ada makanan (nomina)

(2) minum

(2a) Adik minum es (verba)

(2b) Buatlah minuman (nomina)

\section{(3) jahit}

(3a) Ayo jahit bajumu (verba)

(3b) Jangan diletakkan di atas jahitan (nomina)

Pada data di atas kata makan, minum, dan jahit berkategori verba, yang masingmasing menduduki fungsi predikat pada data kalimat (1a,2a,3a). Manakala susunannya diubah dan ditambahkan sufiks - anseperti pada data kalimat (4-2:1b,2b,3b) menjadi makanan, minuman, dan jahitan secara serta merta berubah menjadi nomina dan bergeser pula status fungsinya. Pada data kalimat (1b) makanan menduduki fungsi 
objek. Data kalimat (2b) minuman menduduki fungsi subjek. Data kalimat (4-2:3b) jahitan menduduki fungsi keterangan.

Penambahan sufiks - anpada bentuk dasar verba agaknya terjadi perubahan kategori, yakni verba menjadi nomina. Perubahan kategori ini diakibatkan juga adanya pergeseran fungsi dari verba ke argument (O:N, O:N, Ket:N). Namun, yang perlu difoluskan bahwa sufiks - an hadir karena dibutuhkan oleh verba atau kehadiran sufiks anditentukan oleh verbanya.

\section{Kategori Nomina}

(1) batu $\rightarrow$ Di atas batu. (nomina)

(2) sekolah $\rightarrow$ Adik pergi ke sekolah. (nomina)

(3) bulan $\rightarrow$ Gajinya tiap bulan. (nomina)

Pada data di atas sufiks - an dapat dengan leluasa bergabung dengan nomina dan tampaknya tidak terjadi perubahan fungsi, yakni tetap berkategori nomina.

\section{Kategori Adjektiva}

(1) jauh

(1a) Agak jauh (adjektiva)

(1b) Dari jauhan sudah tampak. (nomina)

(2) kaget

(2a) Cukup kaget (adjektiva)

(2b) Yang kagetan tidak boleh masuk. (nomina)

(3) gugup

(3a) Sangat gugup (adjektiva)

(3b) Yang gugupan itu duduk di belakang. (nomina)

Pada data di atas tampaknya sufiks -an dapat melekat pada satuan berkategori adjektiva $(1,2,3)$. Namun, daya lekat sufiks -an mampu mengubah kategori menjadi nomina. Data 4-4:1b jauh $\rightarrow$ jauhan (adjekif menjadi nomina) test ujinya dengan penambahan preposisi dari $\rightarrow$ dari jauhan (berkategori nomina). Data (2b) kaget $\rightarrow$ kagetan (adjektif menjadi nomina) diuji dengan penambahan partikel yang $\rightarrow$ yang kagetan (berkategori nomina). Hal ini pun terjadi pada data (3b) gugup $\rightarrow$ gugupan (adjektif menjadi nomina). Dengan demikian, penambahan sufiks -an pada satuan dasar adjektiva akan mengubah fungsi menjadi nomina.

\section{Kategori Adverbial}

(1) habis 
(1a) Sehabis-habisnya (adverbia)

(1b) Dia dikritik habis-habisan (adverbia)

(2) besar

(2a) Sebesar-besarnya (adverbia)

(2b) Pesta itu dirayakan besar-besaran (adverbia)

(3) kecil

(3a) Sekecil-kecilnya (adverbia)

(3b) Nenek itu berdagang kecil-kecilan (adverbia)

Pada data (1) kata habis pada sehabis-habisnya (1a) yang berkategori adverbia bila dilekati dengan sufiks -an menjadi habis-habisan (4-5:1b) tetap berkategori adverbial. Hal ini juga berlaku pada data (2 dan 3). Tampaknya pada kategori adverbia penambahan sufiks - an tidak mengubah kategori kata, yakni tetab berkategori adverbia.

\section{Kategori Numeralia}

(1) satu

(1a) Satu ekor (numeralia)

(1b) Dipecah berdasarkan satuan (nomina)

(2) sepuluh

(2a) Sepuluh buah (numeralia)

(2b) Satu kotak berisi sepuluhan. (nomina)

(3) seribu

(3a) Seribu rupiah

(3b) Aku hanya punya seribuan (nomina)

Sufiks - an memiliki potensi melakat pada satuan yang berkategori numeralia: satu, sepuluh, dan seribu $(1,1 \mathrm{a} ; 2,2 \mathrm{~b} ; 3,3 \mathrm{~b})$. Tampaknya sufiks -an memiliki kemampuan untuk mengubah kategori dari satuan berkategori numeralia menjadi nomina, terlihat pada data $(1 \mathrm{~b}, 2 \mathrm{~b}, 3 \mathrm{~b})$ satu $\rightarrow$ satuan, sepuluh $\rightarrow$ sepuluhan, dan seribu $\rightarrow$ seribuan.

Berdasarkan kemungkinan-kemungkian yang telah dicoba di atas dapat ditarik suatu kepastian dari perilaku sintaksis sufiks -an, yakni:

1) Sufiks - an mempunyai daya lekat pada semua kategorial kata.

2) Sufiks - an mempunyai kemampuan mengubah semua kategorial kata ke dalam kategori nomina kacuali pada kategori adverbial.

3) Sufiks - an pada relasi sentencial S-V-O selalu menempati posisi argument. 
4) Sufiks - an pada relasi sentencialnya kehadirannya ditentukan oleh watak V-nya.

Dengan demikian dapat dibentuk kaidah dengan formula sebagai berikut.

Kaidah 3: Kedudukan Sufiks -an pada Relasi Sentencial

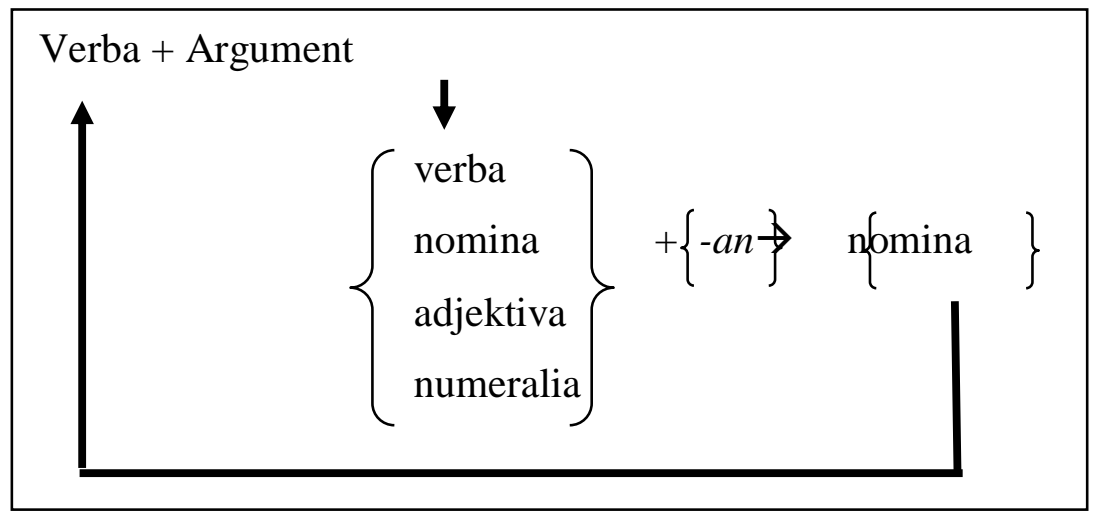

\section{Aspek Semantik}

Bentuk dan makna tidak dapat dilepaskan begitu saja bila menganalisis satuan lingual, termasuk dalam menganalisis sufiks - an. Hal ini terjadi karena saling terkait, manakala ada perubahan bentuk biasanya disertai adanya perubahan makna. Bahkan terjadi pula bentuk yang sama pun kadangkala memiliki makna yang berbeda (homonimi) atau kadangkala terjadi pergeseran makna pada pada satuan lingual (leksikalisasi).

Penentuan makna sufiks - an pada kata polimorfemis tidak lepas dari satuan sintaksis yang lain. Dengan demikian, pada saat penentuan makna sufiks -an diperhatikan pula rentetan sintaksis yang menyertainya (frasa, klausa, kalimat).

\section{Bentuk Dasar Verbal}

(1) makanan

(1a) Di meja ada makanan.

(1b) Makanan telah siap.

Makna sufiks - an berdasar data di atas adalah sesuatu yang (siap) di....

(1) jahitan

(1a) Jangan diletakkan di atas jahitan..

(1b) Ambilkan jahitan itu..

Makna sufiks - an berdasar data di atas adalah hasil.

(1) tiduran

(1a) Tidak boleh tiduran di kursi. 
(1b) Tidak boleh tiduran di lantai.

Makna sufiks - an berdasar data 4-9 adalah melakukan perbuatan.

Sufiks -an bila melekat pada bentuk dasar verba mempunyai makna sebagai berikut.

1) Sesuatu yang di....

2) Hasil.

3) Melakukan perbuatan.

Sufiks - an pada satuan verba polimorfemik menyatakan 'sesuatu yang di...' dan 'hasil' memiliki kecenderungan menduduki argument. Sufiks - an pada satuan verba polimorfemik menyatakan makna 'melakukan perbuatan' memiliki kecenderungan menduduki fungsi predikat.

\section{Bentuk Dasar Nomina}

(1) Batuan $\rightarrow$ Terbuat dari batuan.

Makna sufiks - an berdasar data di atas adalah terdiri atas/berbagai/himpunan.

(1) Sekolahan $\rightarrow$ Lomba itudiadakan di sekolahan

Makna sufiks - an berdasar data di atas adalah tempat.

(1) Bulanan $\rightarrow$ Sebagai buruh bulanan.

Makna sufiks - an berdasar data di atas adalah tiap-tiap

Sufiks - an bila melekat pada bentuk dasar berkategori nomina mempunyai makna antara lain.

1) Terdiri atas atau berbagai atau himpunan.

2) Tempat

3) Tiap-tiap.

Berdasarkan deskripsi data di atas tampaknya sufiks - an memiliki makna 'tiaptiap' bila melekat pada satuan bentuk dasar nomina yang merujuk pada 'waktu'

\section{Bentuk Dasar Adjektiva}

(1) Dari jauhan.

(2) Yang kagetan tidak boleh masuk.

Sufiks -an bila melekat pada bentuk dasar adjektiva mempunyai makna, sebagai berikut.
1) Tempat
2) Memiliki sifat. 
Tampaknya sufiks -an dalam satuan adjektiva polimormefis memiliki makna 'tempat' bila berposisi pada frase preposisional. Manakala sufiks -an dalam satuan adjektiva polimorfemis memiliki makna 'seperti pada bentuk dasarnya' jika satuan dasarnya berupa kata sifat.

\section{Bentuk Dasar Adverbia}

(1) Dia dikritik habis-habisan

(2) Pesta itu dirayakan secara besar-besaran.

Tampaknya semua sufiks-an yang melekat pada bentuk dasar adverbial mempunyai makna 'dalam keadaan/secara'.

\section{Bentuk Dasar Numeralia}

(1) Dipecah berdasarkan satuan.

(2) Satu kotak berisi sepuluhan.

Sufiks - an yang melekat pada bentuk dasar numeralia mempunyai makna 'ukuran', yang terperinci atas:

1) Satuan.

2) Beberapa.

3) Sekitar.

\section{Simpulan}

Berdasarkan kajian tipologi terhadap sufiks -an dalam bahasa Indonesia dapat disimpulkan tentang hal-hal yang pasti terhadap sufiks -an, sehingga dapat ditemukan tiga kaidah. Kaidah kedudukan sufiks - an. Sufiks - an baru dikatakan sufiks bila telah melekat pada satuan dasar lain dan berpadu menjadi satuan dasar yang polimorfemis; kaidah kemantapan ujud sufiks - an. Sufiks - an tidak mengalami perubahan bentuk jika digabungkan dengan satuan mana pun, baik satuan kata yang berakhir dengan fonem konsonan atau fonem vokal. Kaidah kedudukan sufiks -an pada relasi sentensial. Dampaknya adalah sufiks - an kehadirannya ditentukan oleh watak verbalnya; sufiks an pada relasi $\mathrm{S}-\mathrm{V}-\mathrm{O}$ selalu menempati fungsi argumen; sufiks -an mempunyai kemampuan mengubah semua kategorial kata ke dalam kategori nomina kecuali pada kategori adverbia. 


\section{Daftar Pustaka}

Greenberg, Joseph H. 1978. "Pernyataan tentang Semestaan Bahasa"

Keraf, Gorys. 1982. Tata Bahasa Indonesia. Ende Flores: Nusa Indah.

Kridalaksana, Harimurti. 1986. Kelas Kata dalam Bahasa Indonesia. Jakarta: Gramedia. Moeliono, Anton M. 1988. Tata Bahasa baku Bahasa Indonesia. Jakarta: Balai Pustaka.

Ramlan, M. 1983. Morfologi: Suatu Tunjauan Deskriptif. Yogyakarta: Karyono.

Soetarno. 1965. Sari Tatabahasa Indonesia. Surakarta: Widya Duta.

Sudaryanto. 1983. Predikat-Objek dalam Bahasa Indonesia: Keselarasan Pola Urutan. Jakarta: Djambatan. 1989. "Perkembangan Tipologi Bahasa: Tinjauan Selayang" dalam Pellba 2. Yogyakarta: Kanisius. 1989. Pemanfaatan Potensi Bahasa. Yogyakarta: Kanisius. . 1993. Metode dan Aneka Teknik Analisis Bahasa. Yogyakarta: Duta Wacana University Press.

Verhaar, J.W.M. 2004. Azas-asas Linguistik Umum. Yogyakarta: Gadjah Mada University Press. 